\title{
Feruloyl esterase immobilization in mesoporous silica particles and characterization in hydrolysis and transesterification
}

\author{
Cyrielle Bonzom ${ }^{1}$, Laura Schild ${ }^{1}$, Hanna Gustafsson ${ }^{2,3}$ and Lisbeth Olsson ${ }^{1 *}$
}

\begin{abstract}
Background: Enzymes display high reactivity and selectivity under natural conditions, but may suffer from decreased efficiency in industrial applications. A strategy to address this limitation is to immobilize the enzyme. Mesoporous silica materials offer unique properties as an immobilization support, such as high surface area and tunable pore size.

Results: The performance of a commercially available feruloyl esterase, E-FAERU, immobilized on mesoporous silica by physical adsorption was evaluated for its transesterification ability. We optimized the immobilization conditions by varying the support pore size, the immobilization buffer and its $\mathrm{pH}$. Maximum loading and maximum activity were achieved at different pHs (4.0 and 6.0 respectively). Selectivity, shown by the transesterification/hydrolysis products molar ratio, varied more than 3 -fold depending on the reaction buffer used and its $\mathrm{pH}$. Under all conditions studied, hydrolysis was the dominant activity of the enzyme. $\mathrm{pH}$ and water content had the greatest influence on the enzyme selectivity and activity. Determined kinetic parameters of the enzyme were obtained and showed that $K_{m}$ was not affected by the immobilization but $k_{\text {cat }}$ was reduced 10 -fold when comparing the free and immobilized enzymes. Thermal and pH stabilities as well as the reusability were investigated. The immobilized biocatalyst retained more than $20 \%$ of its activity after ten cycles of transesterification reaction.

Conclusions: These results indicate that this enzyme is more suited for hydrolysis reactions than transesterification despite good reusability. Furthermore, it was found that the immobilization conditions are crucial for optimal enzyme activity as they can alter the enzyme performance.
\end{abstract}

Keywords: Kinetic parameters, Feruloyl esterase selectivity, Enzyme reusability, E-FAERU, Enzyme stability, Mesoporous silica

\section{Background}

Although enzymes exhibit high reactivity and selectivity in their natural environment, they may suffer from denaturation under reaction conditions that differ from their natural ones, thus restricting their industrial use. One strategy used to solve this problem is to immobilize the enzymes [1]. Immobilized enzymes can exhibit enhanced properties in terms of activity, specificity or

\footnotetext{
* Correspondence: lisbeth.olsson@chalmers.se

${ }^{1}$ Department of Biology and Biological Engineering, Industrial Biotechnology Division, Chalmers University of Technology, SE-412 96 Gothenburg, Sweden

Full list of author information is available at the end of the article
}

selectivity. The proposed mechanisms behind those apparent alterations have been reviewed recently [2]. Enzymes can be immobilized using different techniques such as encapsulation, enzyme cross linking or immobilization on a solid support by physical adsorption or covalent linkages which have been reviewed recently [3]. In this study, immobilization relied on physical adsorption.

Materials made of mesoporous silica (MPS) have recently become interesting as support materials for immobilized enzymes. MPS offers unique properties such as high surface area and tunable pore size over the 
range 2-50 nm [4]. They also have high chemical and mechanical stability [5]. Among the variety of existing MPS materials, SBA-15 (Santa Barbara Amorphous Type 15) present some interesting properties. SBA-15 has a well ordered network of hexagonal silica structures [6] of which the pore size and thickness of the walls can be tuned by varying the synthesis conditions. Both pore size and wall thickness are uniform throughout the material. Different kinds of enzymes, such as feruloyl esterases, lipases, glucose oxidases and papain, have been successfully immobilized in this type of mesoporous support [7-9]. It has also been shown that immobilization can increase the enzyme stability, increasing its half-life by more than 60,000 times in some cases [10]. Furthermore, enzyme immobilization can modify the specific activity of the enzyme or even change its selectivity and specificity in synthetic reactions, almost doubling the final product yield $[2,7,11]$. These findings are promising, and indicate that it could be possible to tune the activity of an enzyme simply by immobilizing it in a particular way. Moreover, SBA-15 can provide a sheltered environment for the enzymes, as is the case with other porous materials. It has been suggested that the porous network in which the enzymes are immobilized can create concentration gradients $(\mathrm{pH}$, solvent, substrate, etc.), thereby having a positive effect on the biocatalyst [2]. The properties of MPS thus make it an attractive immobilization support.

Feruloyl esterases (FAEs), also known as ferulic acid esterases, cinnamoyl esterases or cinnamoyl ester hydrolases, are enzymes belonging to a subclass of carboxylic ester hydrolases (E.C. 3.1.1.73). In nature, these enzymes catalyze the hydrolysis of ester linkages, releasing ferulic acid (FA) and other hydroxycinnamic acids from plant cell wall material. FAEs are of particular importance in the degradation of plant cell walls where they have been shown to act synergistically with other carbohydratedegrading enzymes [12]. FAEs have found applications in many industrial sectors such as the pulp and paper industry, bioethanol production and the feed industry [13].

Other sectors in which applications are found for FAEs are the cosmetic and pharmaceutical industries [13], as FAEs are able to release FA and other hydroxycinnamic acids, which have been reported to have antitumor, antimicrobial and/or antioxidant effects [14]. FAEs can also catalyze the synthesis of various hydroxycinnamic acids through esterification and transesterification reactions $[15,16]$. As with other synthetic reactions, transesterification reactions are more likely to occur when the water content of the reaction medium is low. Reducing the water content decreases the water activity in the reaction system, thereby promoting synthetic reactions, and allowing hydrolytic enzymes to act as biosynthetic tools [7, 17-19]. Being able to synthesize and tune the properties of hydroxycinnamic acids through transesterification would be valuable in expanding their applicability. Modification of hydroxycinnamic acids to alter their solubility or hydrophobicity, may be necessary prior to their use in cosmetic or pharmaceutical products, for formulation purposes. These modifications are difficult using traditional chemistry [13]. The development of enzymatic synthesis tools is thus both attractive and promising.

The objective of this study was to gain insight into how the immobilization of a commercially available FAE, E-FAERU, derived from a rumen microorganism, in MPS by physical adsorption affects the enzyme and its selectivity. The substrates used in the reactions were methyl ferulate (MFA) and 1-butanol. Parameters such as $\mathrm{pH}$, buffer and water content were varied during immobilization to assess their impact on immobilization efficiency and on enzyme selectivity. Another aim of the study was to evaluate the effects of immobilization on the kinetic parameters of the FAE. We first identified the optimum reaction conditions, and then determined the kinetic parameters $\mathrm{K}_{\mathrm{m}}$ and $\mathrm{k}_{\mathrm{cat}}$ using the model substrate MFA. Finally, the industrial potential of the enzyme was investigated by evaluating its stability and reusability.

\section{Methods}

\section{Chemicals and enzyme}

Ferulic acid and methyl ferulate were purchased from Apin Chemicals Ltd. (Abingdon, UK). 1-Butanol, methanol, glacial acetic acid, sodium carbonate and bis(2-hydroxyethyl)amino-tris(hydroxymethyl)methane (Bis-Tris) were purchased from Sigma-Aldrich (St Louis, MO, USA). 3-(N-morpholino)propanesulfonic acid (MOPS) was purchased from Amresco Inc. (Cleveland, OH, USA). Butyl ferulate (BFA) was kindly provided by Evangelos Topakas (National Technical University of Athens, Greece). The enzyme, E-FAERU, a feruloyl esterase from a rumen microorganism was purchased from Megazyme as a monocomponent enzyme (single band on an SDS-PAGE gel) (Bray, Co. Wicklow, Ireland).

\section{Mesoporous silica support}

SBA-15 was used as the MPS support. SBA-15 MPS with three different pore sizes were synthesized using protocols adapted from Zhao et al. [6] Pluronic P123 is used as structure directing agent and TEOS as the silica source. $4.0 \mathrm{~g}$ of P123 was dissolved in $120 \mathrm{~g}$ of $2 \mathrm{M} \mathrm{HCl}$ and $30 \mathrm{~g}$ of deionized water and the mixture was vigorously stirred for $2 \mathrm{~h}$ at $35{ }^{\circ} \mathrm{C} .8 .5 \mathrm{~g}$ of TEOS was added and the solution was stirred at $35{ }^{\circ} \mathrm{C}$ for an additional $24 \mathrm{~h}$. The gel mixture was transferred to stainless steel pressure autoclaves with Teflon containers and was aged for $24 \mathrm{~h}$ at 80,120 or $140{ }^{\circ} \mathrm{C}$, depending on the desired 
pore diameter. The solid precipitate was recovered by vacuum filtration, washed with deionized water and dried. Finally, the template was removed from the product through calcination, by increasing the temperature from room temperature to $500{ }^{\circ} \mathrm{C}$ during $8 \mathrm{~h}$ followed by heating at $500{ }^{\circ} \mathrm{C}$ for another $6 \mathrm{~h}$. The samples were then characterized as described by Gustafsson et al. [20]. The main particle properties are summarized in Table 1 and a TEM image, representative of the different obtained materials and showing their hexagonal pore structure, is presented in the supplementary material (Additional file 1 Figure S1).

\section{Immobilization of the enzyme}

The immobilization procedure was adapted from Thörn et al. [7]. Briefly, the enzyme solution was spin-filtered (Amicon Ultra-0.5 mL $10 \mathrm{~K}$ ultracel membrane, Millipore, Billerica, Massachusetts, USA) with the same buffers as those used during immobilization $(0.2 \mathrm{M}$ phosphate-citrate in the $\mathrm{pH}$ range $4.0-8.0$, or $0.1 \mathrm{M}$ MOPS in the $\mathrm{pH}$ range 6.0-7.5, or $0.1 \mathrm{M}$ Bis-Tris in the $\mathrm{pH}$ range 6.0-7.5). The MPS was washed with immobilization buffer to remove possible residues from material preparation. To evaluate the effect of the immobilization buffer, the enzyme solution was mixed with $2 \mathrm{mg}$ MPS $\left(0.2 \mathrm{mg}_{\mathrm{enz}} \cdot \mathrm{mL}_{\text {buffer }}^{-1}\right.$ and 44 $\left.\mathrm{mL}_{\text {buffer }} \cdot \mathrm{g}_{\mathrm{MPS}}^{-1}\right)$. For activity assays, the enzyme solution was mixed with $20 \mathrm{mg}$ washed MPS $\left(0.4 \mathrm{mg}_{\text {enz }} \cdot \mathrm{mL}_{\text {buffer }}^{-1}\right.$ and $\left.44 \mathrm{~mL}_{\text {buffer }} \cdot \mathrm{g}_{\text {MPS }}^{-1}\right)$. Then left on a rotating wheel (Rotator SB3, Stuart, Stone, Staffordshire, UK) overnight at $40 \mathrm{rpm}$ and room temperature (RT) in a micro-centrifuge tube. Immobilization was stopped by centrifugation (5 min, 15,000 $\times$ g, RT) and the MPS carrying enzymes was washed 3 times with the immobilization buffer to remove unbound enzyme. The MPS was then dried in a vacuum concentrator (RVC 2-18, Christ, Osterode am Harz, Germany) to remove residual water before activity tests were performed.

\section{Loading experiments}

Loading experiments were performed according to the protocol described previously by varying the enzyme concentration from 0.1 to $1 \mathrm{mg}_{\mathrm{enz}} \cdot \mathrm{mL}_{\text {buffer }}^{-1}$. The chosen buffer for the experiments was $0.2 \mathrm{M}$ phosphate-citrate $\mathrm{pH}$ 6.5. The experiments were done in triplicates.

Table 1 Properties of the MPS materials used for enzyme immobilization

\begin{tabular}{lll}
\hline Pore diameter $(\mathrm{nm})$ & $\begin{array}{l}\text { BET surface } \\
\text { area }\left(\mathrm{m}^{2} \cdot \mathrm{g}^{-1}\right)\end{array}$ & $\begin{array}{l}\text { Specific pore } \\
\text { volume }\left(\mathrm{cm}^{3} \cdot \mathrm{g}^{-1}\right)\end{array}$ \\
\hline 10.1 & 439 & 1.11 \\
9.9 & 433 & 1.11 \\
7.8 & 679 & 1.17 \\
5.0 & 924 & 0.73 \\
\hline
\end{tabular}

\section{Determination of adsorption yields and enzyme loading}

The amount of immobilized enzyme was calculated by measuring the amount of residual enzyme in the supernatants after the immobilization process, and in the subsequent washing buffer, using the Biorad DC protein assay kit with bovine serum albumin (BSA) as a standard (Biorad, Hercules, California, USA). The enzyme loading was then calculated as the quantity of adsorbed enzyme per mg MPS.

\section{Enzymatic assays}

All enzymatic assays were performed using MFA as the substrate. In the buffer-butanol mixture used during the transesterification reactions, MFA can be converted to either FA via hydrolysis or BFA via transesterification (see reaction scheme in Fig. 1). Two different types of assay were performed. A spectrophotometric assay when hydrolysis was studied, allowing the detection of MFA and FA; An HPLC measurement when studying transesterification allowing the detection of MFA, FA and BFA. All assays were performed in triplicate. For hydrolysis experiments, corresponding triplicate blanks were made using buffer (the same buffer and $\mathrm{pH}$ as in the reaction) instead of the enzyme and the activity of the enzyme was corrected by the background. The transesterification reaction was performed without adding enzyme and monitored during $48 \mathrm{~h}$. Results showed no difference whether or not MPS were added to the reaction mixture with no detectable conversion of MFA into BFA or FA. Moreover, the MFA concentration remained the same

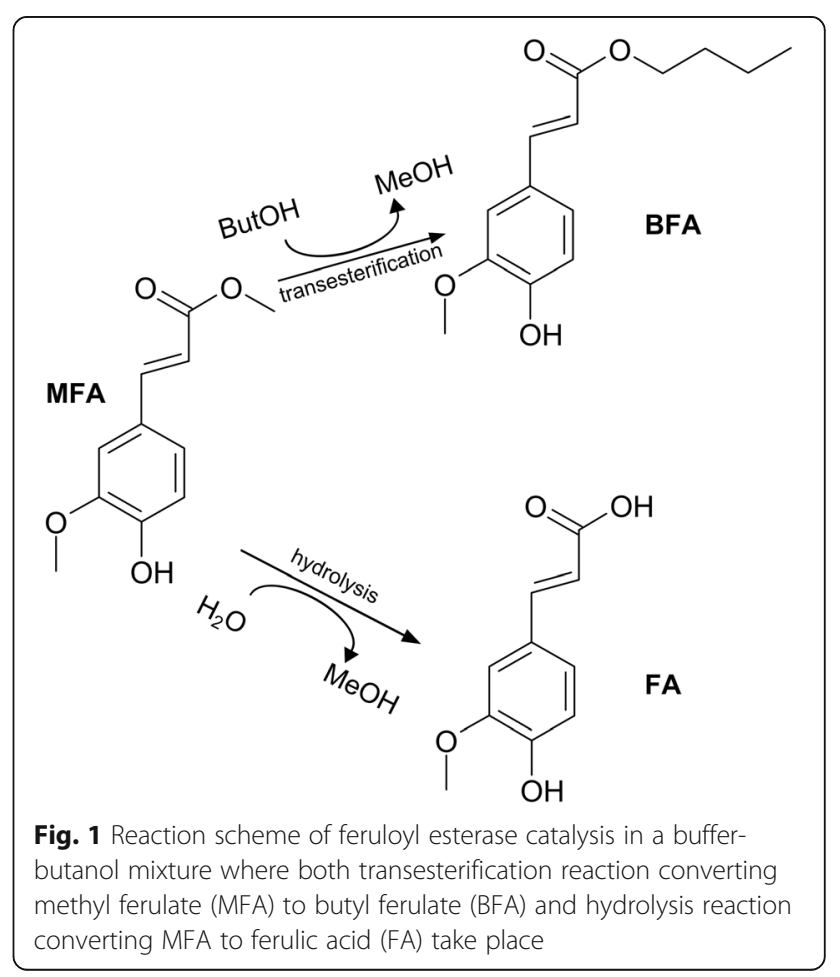


during the time course of the experiment. Consequently, MPS did not as such contribute to the conversion of MFA and addition of enzyme greatly accelerated the reaction towards its thermodynamic equilibrium.

\section{Hydrolysis reactions}

Hydrolysis reactions were performed in buffer using a $0.5 \mathrm{mM}$ MFA stock solution. MFA was prepared by dissolving the powder first in methanol $(5 \%(v / v))$ and then in the buffer $(95 \%(\mathrm{v} / \mathrm{v}))$. For the free enzyme, $900 \mu \mathrm{L}$ of the substrate stock solution was pre-incubated at $40{ }^{\circ} \mathrm{C}$, and the reaction was started by the addition of $300 \mu \mathrm{L}$ of 5000 -fold diluted enzyme in the chosen buffer. For the immobilized enzyme, $0.5 \mathrm{mg}$ MPS carrying the enzyme was resuspended in $300 \mu \mathrm{L}$ buffer. The reaction was started by adding $900 \mu \mathrm{L}$ preheated buffer containing the substrate. The first sample, $100 \mu \mathrm{L}$, was taken immediately, and samples were then taken every minute for $10 \mathrm{~min}$. Samples were immediately quenched by the addition of $110 \mu \mathrm{L} 1 \mathrm{M}$ sodium carbonate. MPS particles were separated from the sample by centrifugation $\left(15,000 \times \mathrm{g}, 5 \mathrm{~min}, 4{ }^{\circ} \mathrm{C}\right)$. MFA and FA were quantified using $200 \mu \mathrm{L}$ quenched samples in micro-titer plates, by spectrophotometry; the absorbance being measured at $340 \mathrm{~nm}$. Standard curves were obtained for MFA and FA for each set of experimental conditions to allow quantification. The activity at $t=10 \mathrm{~min}$ was then calculated according to the formula of Yue et al. [21].

\section{Transesterification reactions}

Transesterification was performed in a mixture of 1butanol and buffer (92.5\% 1-butanol, 7.5\% buffer $(v / \mathrm{v})$ ) in a $1 \mathrm{~mL}$ final volume. A stock solution of $20 \mathrm{mM}$ MFA dissolved in 1-butanol was prepared. Reactions were run in a thermomixer (Eppendorf, Hambourg, Germany) at $40{ }^{\circ} \mathrm{C}$ with shaking at $700 \mathrm{rpm}$. 1-Butanol containing MFA was preheated for $5 \mathrm{~min}$ and the reaction was started by the addition of $75 \mu \mathrm{L}$ of 1000 -fold diluted enzyme, or by the addition of $6 \mathrm{mg}$ dry MPS particles carrying the enzyme and $75 \mu \mathrm{L}$ buffer. The first $50 \mu \mathrm{L}$ sample was taken immediately. The next $50 \mu \mathrm{L}$ sample was taken after $14 \mathrm{~h}$ of incubation, which was the time when product became detectable. $50 \mu \mathrm{L}$ samples were then taken every $1 \mathrm{~h}$ until the reaction had progressed for $22 \mathrm{~h}$. Before each sample was taken out, the microcentrifuge tube was thoroughly vortexed to ensure the mixture was uniform and therefore that the enzyme to reactant ratio was not affected by the sampling. At the enzyme dilution chosen, reactions were linear during the whole course of the experiment which means that the reaction thermodynamic equilibrium was not reached yet. Samples were quenched immediately after removal from the reaction mixture by the addition of glacial acetic acid $(30 \%(v / v)$ final concentration). If not analyzed immediately, the samples were stored at $-20^{\circ} \mathrm{C}$. Quantification of MFA, FA and BFA in the samples was performed using high pressure liquid chromatography (HPLC), as described previously by Thörn et al. [7]. Briefly, samples from transesterification reactions were analyzed using a reversed-phase column (Kinetex 2.6u C18 100A $100 \times 4.6 \mathrm{~mm}$ (Phenomenex, Torrance, California, USA) and isocratic elution with methanol:acetic acid:water $(70: 1: 29 \mathrm{v} / \mathrm{v})$. Standards of MFA, FA and BFA in the range $0.1-20 \mathrm{mM}$ were used for identification and quantification.

\section{Determination of the selectivity ratio during transesterification reactions}

The selectivity ratio was defined as the molar ratio between the transesterification product BFA and the hydrolysis product FA. Transesterification reactions were performed as described previously with the following modifications. To assess the effect of the immobilization $\mathrm{pH}$, the reactions were run in $0.2 \mathrm{M}$ phosphate-citrate buffer at $\mathrm{pH}$ 7.0. To assess the effect of reaction buffer and $\mathrm{pH}$, reactions were run in three different buffers: $0.2 \mathrm{M}$ phosphate-citrate, 0.1 M MOPS and 0.1 M BisTris. Different $\mathrm{pH}$ values were used with each buffer (within their buffering $\mathrm{pH}$ range). The influence of pore size was evaluated by performing immobilization at $\mathrm{pH} 6.5$ and the enzymatic reaction at $\mathrm{pH} 7.0$ in $0.2 \mathrm{M}$ phosphate-citrate buffer. The effect of water content was evaluated by varying the buffer: 1-Butanol ratio from 0.1 to $20 \%(v / v)$ in the reaction system using $0.2 \mathrm{M}$ phosphate-citrate buffer $\mathrm{pH}$ 7.0.

\section{Determination of optimal reaction conditions}

Transesterification and hydrolysis reactions were performed as described previously. The optimum conditions were determined by varying the $\mathrm{pH}$ of the phosphatecitrate buffer from $\mathrm{pH} 5.0$ to $\mathrm{pH} 8.0$ at $40{ }^{\circ} \mathrm{C}$, or the temperature from 15 to $80{ }^{\circ} \mathrm{C}$ at $\mathrm{pH}$ 7.0. When studying transesterification reactions the reaction system was a mixture of buffer and 1-butanol (7.5\% buffer; 92.5\% 1butanol) and only the $\mathrm{pH}$ of the buffer can be controlled.

\section{Determination of kinetic parameters}

Kinetic parameters were investigated at the optimum conditions determined for each of the four reactions studied: hydrolysis and transesterification, with free and immobilized enzyme. Transesterification and hydrolysis reactions were performed as described previously. Substrate concentrations were varied in different intervals for the different reactions: $0.05-2.5 \mathrm{mM}$ for hydrolysis with free or immobilized enzyme; $5-60 \mathrm{mM}$ for transesterification with free enzyme, and 10-200 mM for transesterification with immobilized enzyme. After verifying that all the reactions rates measured were the initial 
rates, the affinity constant $\mathrm{K}_{\mathrm{m}}$ and maximal velocity $\mathrm{V}_{\mathrm{m}}$ were determined by nonlinear regression using the "Enzyme kinetic" module from Sigma-plot (Systat Software Inc., San Jose, USA) which is based on the Michaelis-Menten eq. [22]. The turnover number $\mathrm{k}_{\text {cat }}$ was subsequently calculated. The product formation was quantified as described previously, using standard curves in the same range as the initial substrate concentration.

\section{$\mathrm{pH}$ and temperature stability}

In order to study the $\mathrm{pH}$ stability, enzyme was incubated at room temperature for different times $(0$ to $24 \mathrm{~h})$ in phosphate-citrate buffer in the $\mathrm{pH}$ range 5.0-8.0. To study the temperature stability, the enzyme was incubated in phosphate-citrate buffer at $\mathrm{pH} 7.0$ for different times $(0$ to $24 \mathrm{~h})$ at $\mathrm{RT}, 40$ and $55{ }^{\circ} \mathrm{C}$. After incubation, the hydrolytic activity of the enzyme was assessed at $40{ }^{\circ} \mathrm{C}$ for $10 \mathrm{~min}$, as described previously.

\section{Reusability test}

Ten transesterification reaction cycles were performed consecutively using the same immobilized enzyme in MPS with a $9.9 \mathrm{~nm}$ pore size, using the experimental setup described previously. Each cycle was performed in 92.5\% 1-butanol and 7.5\% 0.2 M phosphate-citrate buffer $(v / v)$ at $30{ }^{\circ} \mathrm{C}$ and $700 \mathrm{rpm}$. After $48 \mathrm{~h}$ the reaction was stopped by centrifugation $(15,000 \times \mathrm{g}, 5 \mathrm{~min}$, RT), the supernatant recovered and stored at $-20{ }^{\circ} \mathrm{C}$ for later analysis. Each cycle lasted for $48 \mathrm{~h}$. A new reaction cycle was then initiated by the addition of fresh substrate solution to the immobilized enzyme without any intermediate washing step. The MFA, FA and BFA contents of the supernatants were determined using HPLC as described previously.

\section{Results}

First, immobilization conditions (buffer, immobilization $\mathrm{pH}$, enzyme loading and support pore size) were optimized. Under these conditions, the enzymatic activity was then studied (reaction buffer $\mathrm{pH}$, temperature, water content). The enzyme was then biochemically characterized. Finally the immobilized biocatalyst was evaluated (stability and reusability).

\section{Optimization of the immobilization parameters}

Several factors during the immobilization process can influence enzyme immobilization and enzyme selectivity $[23,24]$. Therefore, different buffers were tested at various $\mathrm{pH}$ values as well as different enzyme concentration and different pore sizes of the MPS.
Influence of buffer composition and pH and enzyme concentration on enzyme loading and selectivity $\mathrm{pH}$ of different buffers and their influence on the enzyme loading of the MPS were investigated. The transesterification activity (measured as $\mu \mathrm{M}$ of BFA released per mg of enzyme per min) and selectivity (measured as the BFA/FA molar ratio) of the enzymes immobilized were then assessed. The pore size of the MPS were also varied in order to assess their impact on the loading capacity, activity and selectivity. The enzyme concentration applied to the MPS needed for activity detection was also investigated. Results are presented in Fig. 2 and Table 2.

At the same enzyme concentration of $0.2 \mathrm{mg} / \mathrm{mL}$ applied, the best loadings were achieved at different $\mathrm{pH}$ values depending on the buffer. While $\mathrm{pH} 6.0$ was the best $\mathrm{pH}$ for MOPS buffer and Bis-Tris buffer, the obtained enzyme loading was similar within the $\mathrm{pH}$ range 5.0-7.5 for phosphate-citrate buffer. The best enzyme loadings were obtained with phosphate-citrate buffer. It was demonstrated that not only the $\mathrm{pH}$ but also the buffer chemical composition influences the enzyme loading (Fig. 2a).

By applying increasing amounts of enzyme to the MPS, an increasing enzyme loading was observed. The relationship was linear, demonstrating that the maximum enzyme loading capacity of the MPS was not reached in the conditions the assays were performed in the present study (Fig. 2b). The transesterification activity of the samples was evaluated in a mixture of 1butanol and phosphate-citrate buffer, at $\mathrm{pH}$ 7.0. In the defined assay conditions, activity was first detected when enzyme solutions at $0.4 \mathrm{mg} / \mathrm{mL}$ were loaded on MPS. No significant differences were observed between the different enzyme loadings neither on the BFA/FA molar ratio nor on the BFA specific activity when concentrations of enzymes ranging from 0.4 to $1 \mathrm{mg} / \mathrm{mL}$ were applied (data not shown).

Immobilization $\mathrm{pH}$ also influences the enzyme activity and selectivity when the immobilized enzymes are used [24]. Enzymes were immobilized in the different buffers at various pHs using a concentration of $0.4 \mathrm{mg} / \mathrm{mL}$. A similar pattern was observed with this enzyme concentration (data not shown) as the one observed with $0.2 \mathrm{mg} / \mathrm{mL}$ (Fig. 2a). The transesterification reaction was then studied in a mixture of 1-butanol and phosphatecitrate buffer at $\mathrm{pH}$ 7.0. Transesterification reactions were monitored from the moment the product became detectable (14 h of reaction) until $22 \mathrm{~h}$ of reaction. During this time frame, all reactions showed a linear increase of the products which is characteristic of initial rates and therefore the thermodynamic equilibrium was not reached. The influence of immobilization $\mathrm{pH}$ on selectivity was investigated by measuring the BFA/FA 

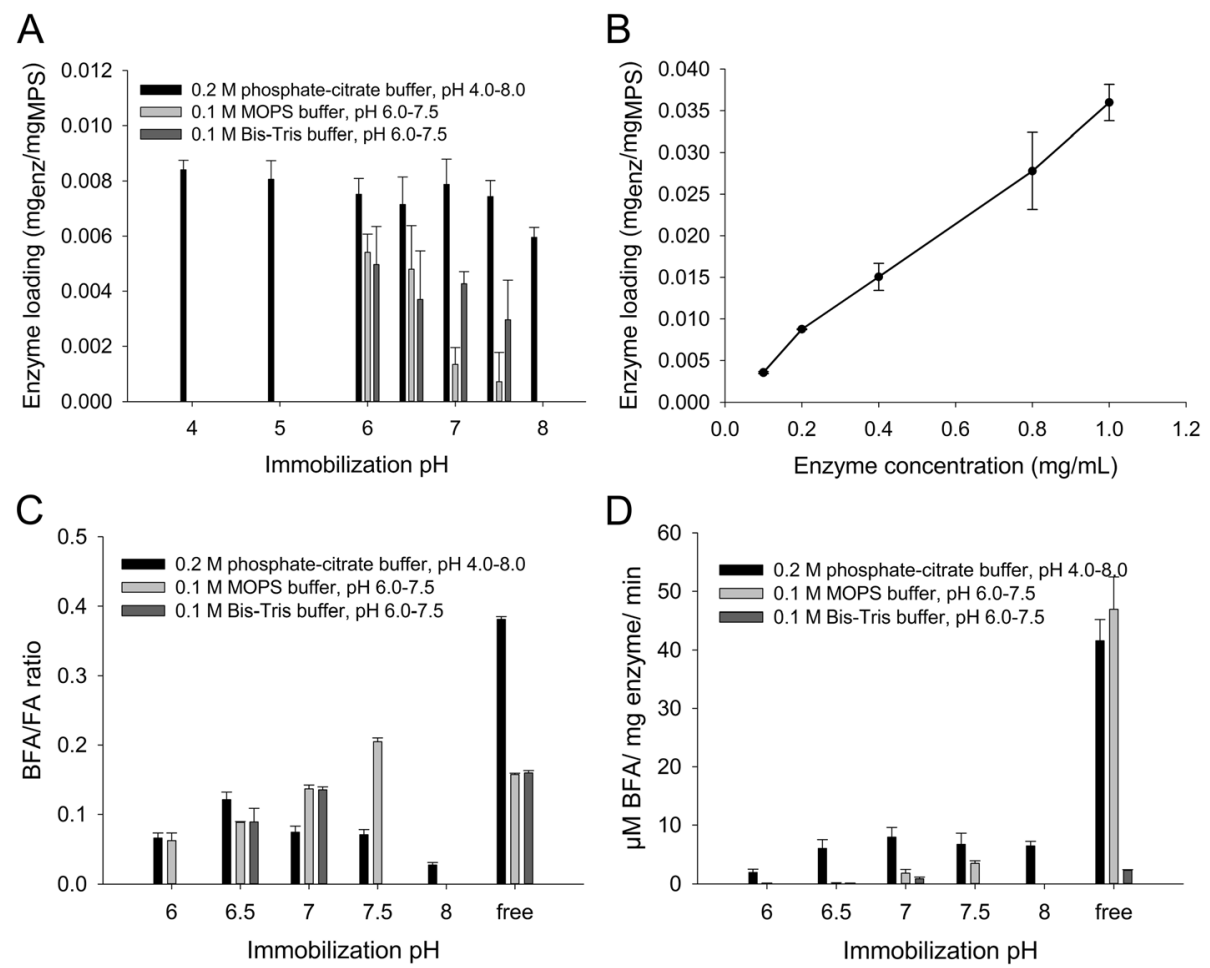

Fig. 2 Effect of immobilization pH and of enzyme concentration on loading and enzymatic activity. a Effect of immobilization pH on the loading using different buffers. $\mathbf{b}$ Effect of enzyme concentration on the loading. $\mathbf{c}$ Influence of the immobilization pH and buffer on the BFA/FA molar ratio. The results are compared to those obtained for the free enzyme at $\mathrm{pH} 7.0$ in the respective buffers. $\mathbf{d}$ Influence of the immobilization $\mathrm{pH}$ on the BFA specific activity. The results are compared to those obtained for the free enzyme at pH 7.0 in the respective buffers. All reactions were in initial velocity. All values are averages of triplicates and the error bars represent one standard deviation

molar ratio. The performance was assessed by the BFA specific activity. Results are shown in Fig. 2a and d. The main activity of the enzyme was hydrolysis under all conditions, since the best BFA/FA molar ratio obtained was 0.4 for the free enzyme. When using phosphatecitrate buffer, the best BFA/FA ratio was obtained at a $\mathrm{pH}$ of 6.5. When using Bis-Tris buffer the FAE showed activity only at immobilization $\mathrm{pH}$ of 6.5 and 7.0, and with MOPS buffer an increasing BFA/FA ratio was observed with increasing $\mathrm{pH}$, showing a maximum of 0.2 at $\mathrm{pH}$ 7.5. Specific activities showed a clear preference of the enzyme for the phosphate-citrate buffer. Phosphate-citrate buffer at a $\mathrm{pH}$ of 6.5 was selected as immobilization buffer for the proceeding experiments, as a compromise between high loading and high selectivity.

\section{Influence of pore size on enzyme activity}

Enzyme loading can also be influenced by the pore size of the particles. For example, if the pores are small, they can limit diffusion of the enzyme inside the pores [20]. Therefore, immobilization was performed in particles with pores of three different diameters, 5, 7.8 and $9.9 \mathrm{~nm}$. The results are presented in Table 2.

Using phosphate-citrate buffer at $\mathrm{pH} 6.5$ as the immobilization buffer resulted in a similar enzyme loading for all three pore diameters tested. The pore size of the MPS did not have any influence on the BFA/FA molar ratio either, but significantly influenced the BFA specific activity. With the smaller pore size $(5 \mathrm{~nm})$ a decrease in the BFA specific activity of almost 2.5 fold was observed, compared with the larger pore sizes.

Table 2 Effect of the pore diameter on enzyme loading and the selectivity of immobilized enzymes

\begin{tabular}{llll}
\hline Pore size $(\mathrm{nm})$ & Loading $\left(\mathrm{mg}_{\mathrm{enz}} / \mathrm{mg}_{\mathrm{MPS}}\right)$ & BFA/FA molar ratio & BFA specific activity $\left(\mu \mathrm{mo} \mathrm{BFA}_{\mathrm{BF}} / \mathrm{mg} \mathrm{enz} / \mathrm{min}\right)$ \\
\hline 5.0 & $0.022 \pm 0.003$ & $0.13 \pm 0.01$ & $3.92 \pm 0.37$ \\
7.8 & $0.021 \pm 0.002$ & $0.11 \pm 0.02$ & $9.63 \pm 1.27$ \\
9.9 & $0.018 \pm 0.003$ & $0.12 \pm 0.01$ & $8.71 \pm 0.34$ \\
\hline
\end{tabular}




\section{Optimization of reaction conditions}

It has been demonstrated previously that the buffer, $\mathrm{pH}$, and water content of the reaction system can affect the enzyme selectivity in synthetic reactions [24]. More specifically, these parameters can affect the molar ratio between the transesterification product BFA and the hydrolysis product FA. Therefore, we studied the influence of the above mentioned parameters. It is also important to evaluate the optimum temperature and $\mathrm{pH}$ when working with enzymes.

\section{Influence of reaction $\mathrm{pH}$ on selectivity}

In order to assess only the effect of the reaction $\mathrm{pH}$, all enzymes were immobilized in $0.2 \mathrm{M}$ phosphate-citrate buffer at $\mathrm{pH}$ 6.5. The immobilized enzyme was then washed, dried and resuspended in a mixture of 1butanol and phosphate-citrate buffer, and the $\mathrm{pH}$ of the reaction buffer was varied from 6.0 to 8.0. The BFA/FA molar ratio decreased with increasing reaction $\mathrm{pH}$ for both free and immobilized enzyme (Fig. 3), indicating that the conditions for hydrolysis were more favorable at higher $\mathrm{pH}$.

\section{Influence of water content}

The water content of the reaction system is an important parameter in synthetic reactions. The water content of the reaction system, expressed as the volumetric percentage, influenced the transesterification/hydrolysis molar ratio as shown in Fig. 4.

The immobilized enzyme was not active below 5\% water content in the reaction, while above $10 \%$ the BFA/ FA ratio seemed to stabilize. The free enzyme was, unexpectedly, more tolerant to low water contents; activity being detected with a water content of $0.1 \%$ of the reaction volume. The optimum water content for the free enzyme was $2.5 \%$, and for the immobilized enzyme, $10 \%$. Taking the BFA specific activity into account, the best results were obtained at $7.5 \%$ and $10 \%$ for the free and immobilized enzyme, respectively. A water content as low as possible which still enabled enough activity was needed, therefore $7.5 \%$ was chosen for the following experiments.

\section{Optimum $\mathrm{pH}$ and temperature for hydrolysis and transesterification reactions}

Following immobilization under the optimal conditions described above, the optimal $\mathrm{pH}$ and temperature for hydrolysis and transesterification reactions were determined for both free and immobilized enzyme. The results are shown in Fig. 5.

The $\mathrm{pH}$ optima were similar for all reaction systems, $\mathrm{pH}$ 7.0, apart from the free enzyme in hydrolysis, which had an optimum at pH 7.5 (Fig. 5a). The latter value differed by one $\mathrm{pH}$ unit from the supplier's data (Megazyme, optimum $\mathrm{pH}$ at 6.5 for hydrolysis of ethyl ferulate in $100 \mathrm{mM}$ sodium phosphate buffer). However, since the present experiment was performed using a different substrate and buffer, the values are not directly comparable. Moreover, it has previously been reported that the optimum $\mathrm{pH}$ can vary by up to $1 \mathrm{pH}$ unit depending on the reaction catalyzed by the enzyme $[25,26]$. An increase of $5{ }^{\circ} \mathrm{C}$ in the optimum temperature for transesterification was observed for the immobilized enzyme compared to the free enzyme (Fig. 5b). Immobilization decreased the optimum temperature when the enzyme was studied in hydrolysis; the optima being at $50{ }^{\circ} \mathrm{C}$ and $40{ }^{\circ} \mathrm{C}$ for free and immobilized enzyme, respectively (Fig. 5b). However, the observed profiles for immobilized enzyme were broader, leading to better relative activities at higher temperatures. Hence, the immobilized enzyme appears to be more stable as it retains more than $60 \%$ of its activity after incubation at $60{ }^{\circ} \mathrm{C}$ for $10 \mathrm{~min}$, while the free enzyme retains less than $25 \%$. The addition of 1 butanol to the mixture, required for the transesterification
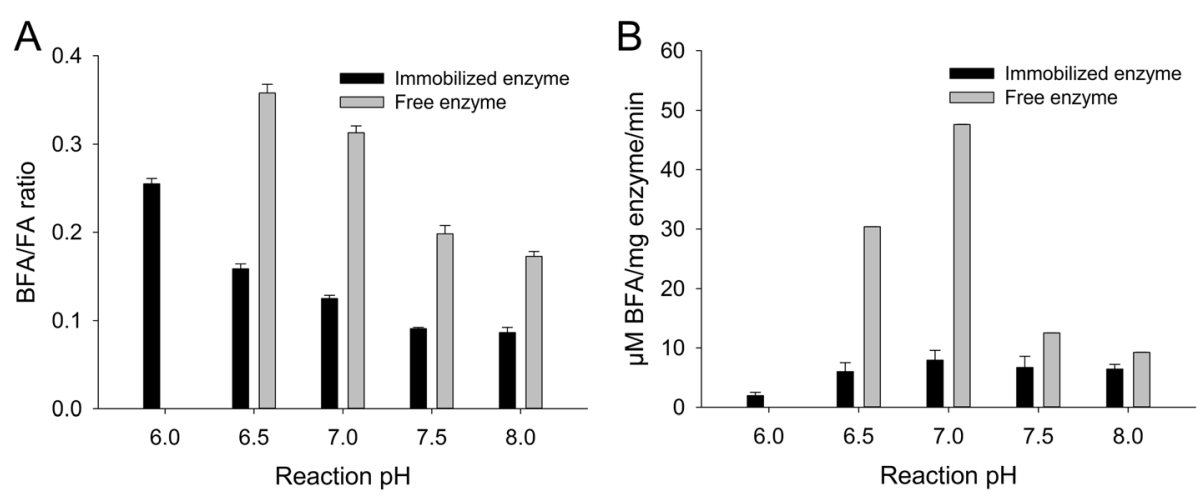

Fig. 3 Effect of the reaction $\mathrm{pH}$ for free and immobilized enzyme. a Effect on the BFA/FA molar ratio. $\mathbf{b}$ Effect on the BFA specific activity. (Reactions were performed in a 1-butanol (92.5\%) phosphate-citrate buffer (7.5\%) mixture. The pH of the buffer fraction was varied from 6.0 to 8.0. Immobilization was performed at $\mathrm{pH} 6.5$ and only the reaction $\mathrm{pH}$ was varied.) All reactions were in initial velocity. The results are the average of triplicate samples, and the error bars represent one standard deviation 

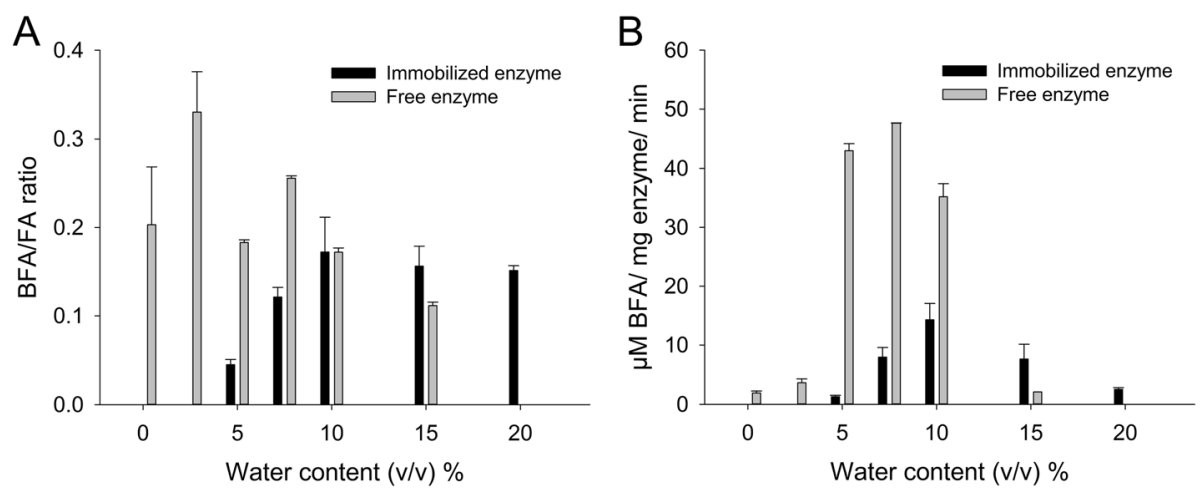

Fig. 4 Influence of the water content on the selectivity of free and immobilized enzyme. a Effect on the BFA/FA ratio. $\mathbf{b}$ Effect on the BFA activity. All reactions were in initial velocity. The results are averages of triplicate samples, and the error bars represent one standard deviation

reaction, caused a decrease in the temperature optima for both the free and the immobilized enzyme of $25{ }^{\circ} \mathrm{C}$ and $10{ }^{\circ} \mathrm{C}$, respectively (Fig. 5b).

\section{Kinetic parameters of the immobilized biocatalyst} In order to assess the effects of immobilization on the enzyme behavior, the kinetic parameters $\left(\mathrm{V}_{\mathrm{m}}, \mathrm{K}_{\mathrm{m}}\right.$ and $\left.\mathrm{k}_{\mathrm{cat}}\right)$ were determined based on the Michaelis-Menten eq. [22]. It could be argued that the transesterification reaction studied was a two-substrate reaction employing butanol and MFA as substrates. However, since the 1-butanol content of the reaction was not varied during the reaction, and 1-butanol was always present in excess, the kinetics for a single-substrate reaction deemed applicable. Moreover, most of the enzyme kinetics can be estimated by the Michaelis-Menten equation when the concentration of one substrate is kept constant [27].

The affinity constant, $K_{m}$, of the enzyme was negligibly affected by immobilization (Table 3), however, a more than 100-fold decrease in the affinity to MFA was observed when transesterification was compared to hydrolysis. The maximum decrease in the turnover number, $\mathrm{k}_{\mathrm{cat}}$, of the enzyme upon immobilization was 10-fold. Furthermore, a 100-fold lower turnover number was observed in transesterification than in hydrolysis, for both the free and the immobilized enzyme. The resulting catalytic efficiency, $\mathrm{k}_{\mathrm{cat}} / \mathrm{K}_{\mathrm{m}}$, of the enzyme was therefore lower when the enzyme was immobilized than its free counterpart: up to 11-fold lower. A dramatic decrease was observed when the transesterification reaction was compared to the hydrolysis reaction with a catalytic efficiency 20,000 times and 43,000 times lower for the free and immobilized enzyme, respectively.

\section{Evaluation of the stability and reusability of the immobilized biocatalyst}

The effect of immobilization on the long-term stability of the FAE at different $\mathrm{pH}$ and temperatures was also investigated. Since the $\mathrm{pH}$ optima were similar for the free and immobilized enzyme (Fig. 5a) similar behavior could be expected in long term stability ( $24 \mathrm{~h})$. However, the free enzyme was more stable at all $\mathrm{pH}$ values
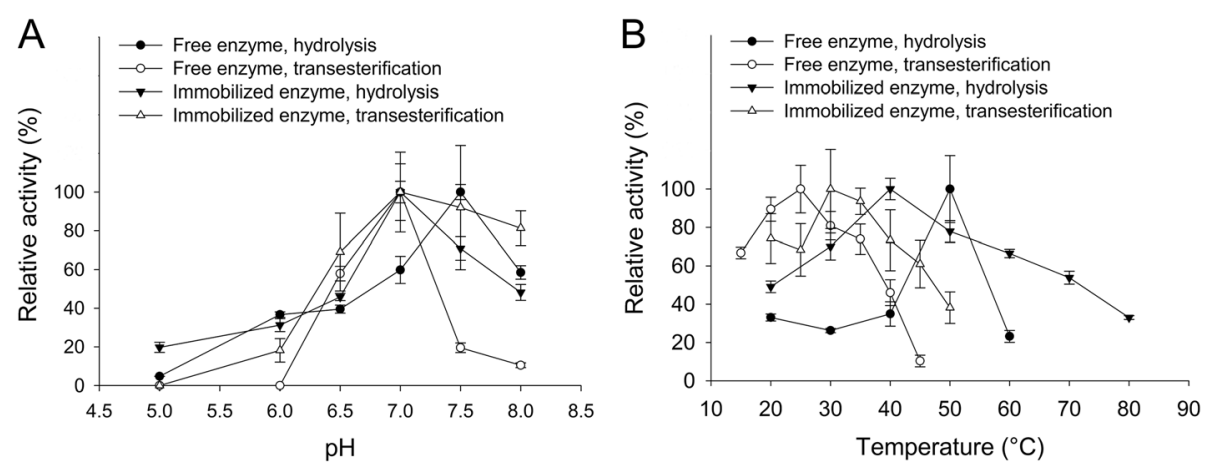

Fig. 5 Determination of $\mathrm{pH}$ and temperature optima for the four reaction systems studied a Optimum $\mathrm{pH}$. Reaction rates measured using phosphate-citrate buffer at $\mathrm{pH} 5.0-8.0$ and $40{ }^{\circ} \mathrm{C}$. b Optimum temperature. The temperature was varied from 15 to $80^{\circ} \mathrm{C}$ and the reaction was performed using phosphate-citrate buffer at $\mathrm{pH}$ 7.0. All reactions were in initial velocity. The results are the average of triplicate samples, and the error bars represent one standard deviation 
Table 3 Kinetic parameters for the four reactions systems studied

\begin{tabular}{llll}
\hline & $K_{m}^{\mathrm{a}}(\mathrm{mM})$ & $\mathrm{k}_{\text {cat }}^{\mathrm{a}}\left(\mathrm{s}^{-1}\right)$ & $\mathrm{k}_{\text {cat }} / \mathrm{K}_{\mathrm{m}}^{\mathrm{a}}\left(\mathrm{s}^{-1} \mathrm{M}^{-1}\right)$ \\
\hline Free enzyme - hydrolysis & $0.43 \pm 0.07$ & $31.4 \pm 2.20$ & $7.29 .10^{4} \pm 1.7 .10^{4}$ \\
Free enzyme - transesterification & $36.0 \pm 14.4$ & $0.14 \pm 0.03$ & $3.79 \pm 2.33$ \\
Immobilized enzyme - hydrolysis & $0.43 \pm 0.06$ & $6.47 \pm 0.34$ & $1.5 .10^{4} \pm 0.3 .10^{4}$ \\
Immobilized enzyme - transesterification & $30.9 \pm 7.30$ & $0.01 \pm 1.10^{-3}$ & $0.35 \pm 0.11$ \\
\hline
\end{tabular}

${ }^{a}$ Data are presented as mean \pm standard deviation

investigated than the immobilized enzyme (Additional file 1 Figure S2). The effect of temperature during a $24 \mathrm{~h}$ incubation showed a similar pattern with only the exception of a slight beneficial effect of immobilization at $55^{\circ} \mathrm{C}$ (Additional file 1 Figure S3).

Despite the fact that the study on the kinetic parameters showed a decrease in the catalytic efficiency upon immobilization (Table 3), immobilizing an enzyme may still be advantageous in terms of the reusability of the biocatalyst. Therefore, the reusability of the immobilized enzyme was assessed over ten $48 \mathrm{~h}$ cycles. During the 20 days of this study, a decrease was observed in both hydrolytic and transesterification activities (Fig. 6), which could have been due to enzyme denaturation or leakage. The transesterification activity decreased more rapidly and, therefore, the enzyme selectivity for transesterification decreased over time. During the last cycle the immobilized enzyme had retained $26 \%$ and $44 \%$ of its transesterification and hydrolysis relative activities respectively.

\section{Discussion}

As enzyme immobilization so far relies mostly on trial and error, getting insight of the behavior of different enzymes is of utmost importance. We therefore investigated the influence of different parameters on the immobilization process and determined the optimum reaction conditions. In addition, optimization also had to be performed to enhance the synthetic transesterification activity of the enzyme and decrease its natural hydrolytic activity. The kinetic parameters were determined under the optimum conditions in order to study the effect of immobilization. The stability and reusability of the immobilized biocatalyst were also investigated.

\section{Immobilization conditions}

When varying the immobilization $\mathrm{pH}$, the differences in loading patterns (Fig. 2a) observed between the three buffers demonstrate that not only the $\mathrm{pH}$, but also the chemical composition of the buffer, must be taken into account when performing immobilization. $\mathrm{pH}$ affects the enzyme surface charge and therefore the electrostatic interactions between the enzyme and the support [23]. The chemical composition of the buffer can also influence enzyme conformation and in turn change the enzyme-support interactions. For instance, MOPS buffer has been shown to interact with the catalytic site of a FAE from Fusarium oxysporum: FoFaeC, in a molecular docking study [24]. Influence of the $\mathrm{pH}$ of the immobilization buffer on the enzyme loading [24] and selectivity [7], has been investigated previously for FoFaeC, resulting in an increase of selectivity for transesterification. In another study, using four different FAEs from the thermophilic fungus Myceliophtora thermophila $\mathrm{C} 1$ and $10.1 \mathrm{~nm}$ pore size SBA-15, the selectivity towards transesterification was decreased for three out of four enzymes [28]. In the present study, using a commercial FAE, immobilization led to a decreased selectivity for
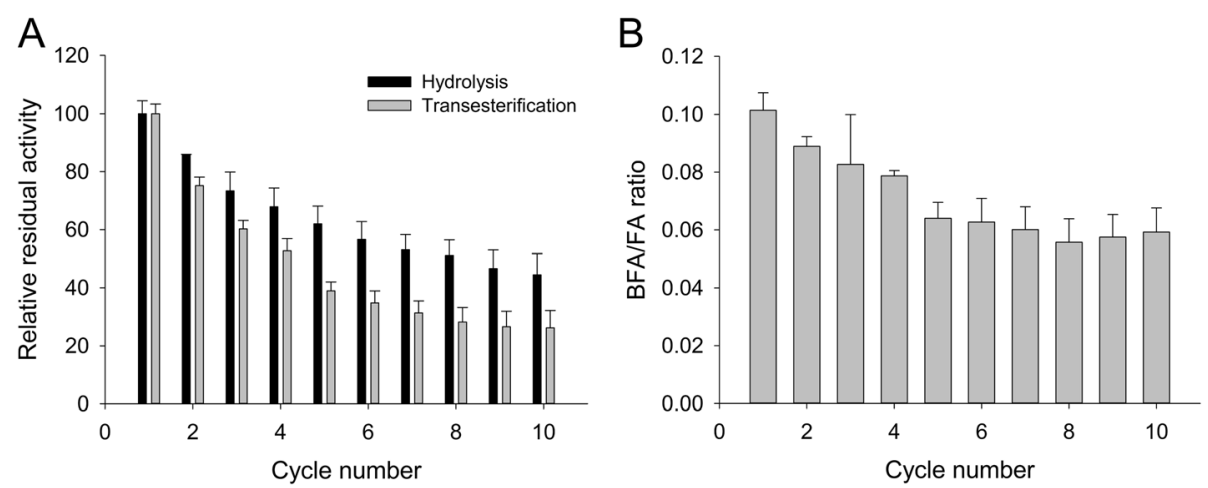

Fig. 6 Evaluation of the reusability of the immobilized enzyme over 10 cycles of $48 \mathrm{~h}$ each. a Relative residual hydrolytic and transesterification activities. $\mathbf{b}$ Evolution of the BFA/FA ratio during the experiment. All reactions were in initial velocity. Data are averages of triplicates. Error bars represent one standard deviation 
transesterification (Fig. 2c). Our findings therefore confirm the hypothesis that the selectivity of an enzyme can be changed by immobilization.

The best loading obtained in the present study $\left(0.036 \mathrm{mg} \cdot \mathrm{mg}^{-1}\right)$ (Fig. $\left.2 \mathrm{~b}\right)$ was in the same range as the one obtained for a horseradish peroxidase (lower than $0.03 \mathrm{mg} \cdot \mathrm{mg}^{-1}$ ) [29]. However, it was lower than those achieved on SBA-15 for some other enzymes, which ranged from 0.044 to $0.185 \mathrm{mg} \cdot \mathrm{mg}^{-1}$ for a lipase, a glucose oxidase and papain $[8,9]$. Low loading can be explained by the low enzyme concentration used in the present study. This was further exemplified by the loading capacity experiment presented in Fig. $2 \mathrm{~b}$ where it was demonstrated that the maximum loading was not reached.

When looking at the immobilization in different pore size materials (Table 2), no difference in loading was observed. This finding supports the hypothesis that the FAE, (which diameter was estimated to be around $4 \mathrm{~nm}$ based on its molecular weight of $29 \mathrm{kDa}$ and assuming that it is perfectly spherical) can enter the pores equally well in all the materials investigated. A lower specific activity was though observed for the material with the smaller pore size. This could be due to limitations on the diffusion of the substrate in the $5 \mathrm{~nm}$ pores since the estimated diameter of the enzyme is around $4 \mathrm{~nm}$. Another possible explanation is increased rigidity of the enzyme due to more attachment points with the support, since the size of the enzyme is expected to be only slightly smaller than the size of the pores. There may also be some loss of activity due to enzyme orientation with its active site facing the walls, thus preventing the substrate from entering the enzyme active site.

Changing the $\mathrm{pH}$ of the reaction mixture may result in a change in the charge distribution of the amino acid residues of the enzyme, inducing slight modifications in their conformation, as well as in the way in which the enzyme interacts with its immobilization support [23]. Such changes in enzyme conformation could explain the shift in selectivity observed when changing the reaction $\mathrm{pH}$ (Fig. 3). The best selectivity ratio was obtained at a reaction $\mathrm{pH}$ of 6.5 and 6.0 for the free and immobilized enzyme, respectively (Fig. 3a). However, a low reaction $\mathrm{pH}$ is not necessarily suitable in an industrial application as the specific activity of the enzyme is not optimal at low $\mathrm{pH}$ as demonstrated by the specific activities (Fig. 3b) which in this case were lower at $\mathrm{pH} 6.0$ than at $\mathrm{pH}$ 7.0. A compromise must thus be made between enzyme selectivity and enzyme specific activity.

Immobilization did not lead to changed substrate affinity A biochemical characterization of the enzyme was performed in four different reaction systems: (i) free enzyme - hydrolysis reaction, (ii) free enzyme - transesterifications reaction, (iii) immobilized enzyme hydrolysis reaction and (iv) immobilized enzyme transesterification reaction. The optimum $\mathrm{pH}$ and temperature of the enzyme were investigated first. The free enzyme optimum $\mathrm{pH}$ was found to be 7.5 (Fig. 5a). When looking at the immobilized enzyme, optimum $\mathrm{pH}$ decreased to 7.0. A shift in $\mathrm{pH}$ optimum upon immobilization has been reported previously for another FAE [7], and could be explained by the different microenvironment inside the pores of mesoporous materials $[2,4]$.

The optimum temperature of the free and immobilized enzymes studied in transesterification were decreased compared with the enzymes studied in hydrolysis (Fig. 5b). When the enzyme was free, a $15{ }^{\circ} \mathrm{C}$ decrease was observed. When it was immobilized the decrease was of $10{ }^{\circ} \mathrm{C}$. This points to the fact that 1 butanol has a negative effect on the thermostability of the enzyme which is consistent with the fact that enzymes usually exhibit lower activities in organic solvents than in aqueous systems due to partial or complete denaturation of the enzyme [30]. The observed decrease in the temperature optima for the immobilized enzyme was less dramatic. Together with the broader profiles observed, this may indicate that enzyme immobilization had a thermo-stabilizing effect, and a possible sheltering effect of the MPS pore system. The stabilizing effect of immobilization has been reported for other enzymes, and could be due to reduced flexibility of the enzyme due to attachment to the support, thus preventing thermal denaturation and reducing the negative effect of solvents such as 1-butanol which are known to destabilize protein structures [11].

Upon immobilization, $\mathrm{K}_{\mathrm{m}}$ did not change, however, $\mathrm{k}_{\mathrm{cat}}$ was decreased (Table 3); suggesting that there were no limitations on diffusion or mass transfer with the pore diameter used in these experiments $(9.9 \mathrm{~nm})$. It can therefore be concluded that immobilization reduced the reaction rate of the enzyme. Changes in kinetic parameters have been observed previously in other immobilized enzymes. A tendency towards positive effects has been seen in the case of lipases, with almost a doubling of the maximal velocity, $V_{m}[31,32]$, while negative effects have been reported for 2,3-dihydroxybiphenyl 1,2-dioxygenase immobilized on SBA-15, for which $K_{m}$ increased 2.8 times and $\mathrm{k}_{\text {cat }}$ decreased nearly 4-fold [33].

\section{Stability and reusability}

It was clear that immobilization did not have a long-term stabilizing effect. It is known that physical adsorption is not the best strategy for improving the stability of an enzyme [2]. However, for this enzyme it was observed no improvement in long-term stability due to immobilization but also minimal effects of immobilization on the optimal 
reaction conditions as well as minimal effects of immobilization on the enzyme selectivity. Taken together, these results suggest a naturally high rigidity of the enzyme, at least in the area around its active site [2].

Looking into the reusability of the immobilized biocatalyst in transesterification, over ten cycles of $48 \mathrm{~h}$, a shift in selectivity towards hydrolysis was observed (Fig. 6). Despite that, the immobilized enzymes retained $26 \%$ and $44 \%$ of their transesterification and hydrolysis relative activities, respectively, at the end of the experiment. Considering the harsh conditions $(92.5 \%$ butanol) in which the enzymes were put, the retained activities can be considered good. However, it is likely that no gain in terms of the total amount of BFA produced would be obtained by immobilizing this enzyme on this type of support, since the transesterification activity of the free enzyme was higher than the one of the immobilized enzyme (Fig. 3b). In the present study, enzymes immobilized on MPS were dried before being used in transesterification reactions. One way to improve the BFA yield of immobilized enzymes might be to replace the drying step by solvent rinsing as it has been shown to improve the productivity of a FAE from Myceliophtora thermophila $\mathrm{C} 1$ from 3 to $5 \mathrm{mmol}_{\mathrm{BFA}} / \mathrm{g}_{\mathrm{enz}} / \mathrm{h}$ [28].

Because of its inherently good stability, this enzyme has some potential to become a good immobilized biocatalyst. But more work is needed to find the appropriate support and/or immobilization technique. It has also been shown that the solvent-buffer system used influences the reaction rate [34], which could also offer means of improving the enzyme performance. Among the parameters investigated, the water content and the $\mathrm{pH}$ of the buffer, during both immobilization and reaction, proved to be critical in improving the transesterification ratio.

\section{Conclusions}

Immobilizing the FAE: E-FAERU resulted in a lowered transesterification efficiency. In earlier studies, changes of selectivity have also been observed upon immobilization of FAEs on SBA-15. Overall, regarding the selectivity of EFAERU, the hydrolysis reaction was preferred by the enzyme regardless if it was free or immobilized. The longterm stability of the immobilized FAE was improved at $55^{\circ} \mathrm{C}$, whereas no improvement was observed under other conditions. However, improvements in short-term stability of more than 2-fold were obtained when defining the temperature profile. Under optimized immobilization and reaction conditions it was demonstrated that immobilization did not affect the $\mathrm{K}_{\mathrm{m}}$ of the studied FAE. However, the turnover number, $\mathrm{k}_{\text {cat }}$, decreased, leading to a decrease in the overall catalytic efficiency. The findings of this study have also underlined the importance of the choice of $\mathrm{pH}$ and buffer during the immobilization process. Overall, this demonstrates that the results are enzyme-specific, and cannot be regarded as reflecting the general behavior of FAEs in MPS.

\section{Additional file}

\begin{abstract}
Additional file 1: TEM image of the used MPS and stability evaluation of the FAE. Figure S1. TEM image of the calcined SBA-15 mesoporous silica material with a $9.9 \mathrm{~nm}$ pore size used in this study. Figure $\mathbf{S 2}$. $\mathrm{pH}$ stability of the enzyme during $24 \mathrm{~h}$. Four $\mathrm{pH}$ values were assessed in $0.2 \mathrm{M}$ phosphate-citrate buffer at room temperature. (A) Free enzyme. (B) Immobilized enzyme. Data are averages of triplicates. Error bars represent one standard deviation. Figure $\mathbf{S 3}$. Temperature stability of the enzyme during $24 \mathrm{~h}$. Three temperatures were tested in $0.2 \mathrm{M}$ phosphate-citrate buffer pH 6.5. (A) Free enzyme. (B) Immobilized enzyme. Data are averages of triplicates. Error bars represent one standard deviation. (DOCX $175 \mathrm{~kb})$
\end{abstract}

\section{Abbreviations}

BFA: Butyl ferulate; Bis-Tris: bis(2-hydroxyethyl)amino-

tris(hydroxymethyl)methane; BSA: Bovine serum albumin; FA: Ferulic acid; FAE: Feruloyl esterase; HPLC: High pressure liquid chromatography; MFA: Methyl ferulate; MOPS: 3-(N-morpholino)propanesulfonic acid; MPS: Mesoporous silica particles; RT: Room temperature; SBA-15: Santa Barbara Amorphous Type 15

\section{Acknowledgements}

The authors thank Milene Zezzi Do Valle Gomes and Anders Palmqvist for providing some of the MPS used in this manuscript, Evangelos Topakas for providing the BFA and George Anasontzis for fruitful discussions on this manuscript.

\section{Funding}

This research was funded by the Swedish Research Council (VR grant 349-2007-8680) via the Linnaeus Centre for Bio-inspired Supramolecular Function and Design - SUPRA

Availability of data and materials

All data generated or analyzed during this study are included in this published article and its supplementary information files or available from the corresponding author on reasonable request.

\section{Authors' contributions}

CB designed and performed some of the experiments, participated in data analysis and wrote the manuscript, LS performed some of the experiments, participated in data analysis and reviewed the manuscript, HG synthesized the MPS used for the study and reviewed the manuscript, LO designed the experiments, participated in data analysis and reviewed the manuscript.

All authors read and approved the final manuscript.

\section{Authors' information \\ Not applicable.}

Ethics approval and consent to participate

Not applicable.

\section{Consent for publication}

Not applicable.

\section{Competing interests}

The authors declare that they have no competing interests

\section{Publisher's Note}

Springer Nature remains neutral with regard to jurisdictional claims in published maps and institutional affiliations. 


\section{Author details}

'Department of Biology and Biological Engineering, Industrial Biotechnology Division, Chalmers University of Technology, SE-412 96 Gothenburg, Sweden. ${ }^{2}$ Department of Chemical and Biological Engineering, Applied Surface Chemistry Division, Chalmers University of Technology, SE-412 96 Gothenburg, Sweden. ${ }^{3}$ Department of Applied Physics, Biological Physics Division, Chalmers University of Technology, SE-412 96 Gothenburg, Sweden.

Received: 28 June 2017 Accepted: 25 January 2018

Published online: 02 February 2018

\section{References}

1. Hudson S, Cooney J, Magner E. Proteins in mesoporous silicates. Angew Chem Int Ed. 2008:47:8582-94.

2. Rodrigues RC, Ortiz C, Berenguer-Murcia Á, Torres R, Fernández-Lafuente R. Modifying enzyme activity and selectivity by immobilization. Chem Soc Rev. 2013;42:6290-307

3. Datta S, Christena LR, YRS R. Enzyme immobilization: an overview on techniques and support materials. 3 Biotech. 2013;3:1-9.

4. Carlsson N, Gustafsson H, Thörn C, Olsson L, Holmberg K, Åkerman B. Enzymes immobilized in mesoporous silica: a physical-chemical perspective. Adv Colloid Interf Sci. 2014;205:339-60.

5. Magner E. Immobilisation of enzymes on mesoporous silicate materials. Chem Soc Rev. 2013:42:6213-22.

6. Zhao D, Feng J, Huo Q, Melosh N, Fredrickson GH, Chmelka BF, et al. Triblock copolymer syntheses of mesoporous silica with periodic 50 to 300 angstrom pores. Science. 1998;279:548-52.

7. Thörn C, Gustafsson H, Olsson L. Immobilization of feruloyl esterases in mesoporous materials leads to improved transesterification yield. J Mol Catal B Enzym. 2011;72:57-64.

8. Ikemoto H, Mossin SL, Ulstrup J, Chi Q. Probing structural and catalytic characteristics of galactose oxidase confined in nanoscale chemical environments. RSC Adv. 2014:4:21939-50.

9. Hartmann M, Kostrov X. Immobilization of enzymes on porous silicas benefits and challenges. Chem Soc Rev. 2013:42:6277-89.

10. Guisán JM, Bastida A, Cuesta C, Fernandez-Lufuente R, Rosell CM. Immobilization-stabilization of a-chymotrypsin by covalent attachment to aldehyde-agarose gels. Biotechnol Bioeng. 1991;38:1144-52.

11. Mateo C, Palomo JM, Fernandez-Lorente G, Guisan JM, Fernandez-Lafuente R. Improvement of enzyme activity, stability and selectivity via immobilization techniques. Enzym Microb Technol. 2007:40:1451-63.

12. Faulds CB. What can feruloyl esterases do for us? Phytochem Rev. 2010;9:121-32

13. Topakas E, Vafiadi C, Christakopoulos P. Microbial production, characterization and applications of feruloyl esterases. Process Biochem. 2007:42:497-509.

14. Heleno SA, Martins A, Queiroz MJRP, Ferreira ICFR. Bioactivity of phenolic acids: metabolites versus parent compounds: a review. Food Chem. 2015; 173:501-13.

15. Vafiadi C, Topakas E, Alissandratos A, Faulds CB, Christakopoulos P. Enzymatic synthesis of butyl hydroxycinnamates and their inhibitory effects on LDL-oxidation. J Biotechnol. 2008;133:497-504.

16. Zeng $Y$, Yin X, Wu M-C, Yu T, Feng F, Zhu T-D, et al. Expression of a novel feruloyl esterase from aspergillus oryzae in Pichia Pastoris with esterification activity. J Mol Catal B Enzym. 2014;110:140-6.

17. Zaks A, Klibanov AM. The effect of water on enzyme action in organic media. J Biol Chem. 1988;263:8017-21.

18. Zaks A, Klibanov AM. Enzymatic Catalysis in nonaqueous solvents. J Biol Chem. 1988;263:3194-201.

19. García-Alles LF, Gotor V. Lipase-catalyzed transesterification in organic media: solvent effects on equilibrium and individual rate constants. Biotechnol Bioeng. 1998;59:684-94.

20. Gustafsson H, Thörn C, Holmberg K. A comparison of lipase and trypsin encapsulated in mesoporous materials with varying pore sizes and $\mathrm{pH}$ conditions. Colloids Surf B Biointerfaces. 2011:87:464-71.

21. Yue Q, Yang HJ, Cao YC, Zhang DF, Jiang YH, Wang JQ. Feruloyl and acetyl esterase production of an anaerobic rumen fungus Neocallimastix sp. YQ2 effected by glucose and soluble nitrogen supplementations and its potential in the hydrolysis of fibrous feedstuffs. Anim Feed Sci Technol. 2009;153:263-77.
22. Johnson KA, Goody RS. The original Michaelis constant: translation of the 1913 Michaelis-Menten paper. Biochemistry (Mosc). 2011:50:8264-9.

23. Hlady V, Buijs J. Protein Adsorption on solid surfaces. Curr Opin Biotechnol. 1996:7:72-7.

24. Thörn C, Udatha DBRKG, Zhou H, Christakopoulos P, Topakas E, Olsson L. Understanding the $\mathrm{pH}$-dependent immobilization efficacy of feruloyl esterase-C on mesoporous silica and its structure-activity changes. J Mol Catal B Enzym. 2013;93:65-72.

25. Klezovitch O, Brandenburger $Y$, Geindre M, Deshusses J. Characterization of reactions catalysed by yeast phosphatidylinositol synthase. FEBS Lett. 1993:320:256-60.

26. RNA R, Jongsareejit B, Fujiwara S, Imanaka T. Characterization of recombinant glutamine synthetase from the hyperthermophilic archaeon Pyrococcus sp. strain KOD1. Appl Environ Microbiol. 1997;63:2472-6.

27. Fersht A. Structure and Mechanism in Protein Science: A Guide to Enzyme Catalysis and Protein Folding. 1st ed. W. H. Freeman; 1999. ISBN 0-71673268-8.

28. Hüttner S, Zezzi Do Valle Gomes M, lancu L, Palmqvist A, Olsson L. Immobilisation on mesoporous silica and solvent rinsing improve the transesterification abilities of feruloyl esterases from Myceliophthora thermophila. Bioresour Technol. 2017;239:57-65.

29. Takahashi H, Li B, Sasaki T, Miyazaki C, Kajino T, Inagaki S. Immobilized enzymes in ordered mesoporous silica materials and improvement of their stability and catalytic activity in an organic solvent. Microporous Mesoporous Mater. 2001;44-45:755-62.

30. Doukyu N, Ogino H. Organic solvent-tolerant enzymes. Biochem Eng J. 2010;48:270-82.

31. Verma ML, Naebe M, Barrow CJ, Puri M. Enzyme immobilisation on aminofunctionalised multi-walled carbon nanotubes: structural and biocatalytic characterisation. PLoS One. 2013:8:e73642.

32. Cabrera-Padilla RY, Albuquerque M, Figueiredo RT, Fricks AT, Franceschi E, Lima ÁS, et al. Immobilization and characterisation of a lipase from a new source, bacillus sp. ITP-001. Bioprocess Biosyst Eng. 2013;36:1385-94.

33. Qu Y, Kong C, Zhou H, Shen E, Wang J, Shen W, et al. Catalytic properties of 2,3-dihydroxybiphenyl 1,2-dioxygenase from Dyella Ginsengisoli LA-4 immobilized on mesoporous silica SBA-15. J Mol Catal B Enzym. 2014;99:136-42.

34. Topakas E, Vafiadi C, Stamatis H, Christakopoulos P. Sporotrichum thermophile type C feruloyl esterase (StFaeC): purification, characterization, and its use for phenolic acid (sugar) ester synthesis. Enzym Microb Technol. 2005:36:729-36.

\section{Submit your next manuscript to BioMed Central and we will help you at every step:}

- We accept pre-submission inquiries

- Our selector tool helps you to find the most relevant journal

- We provide round the clock customer support

- Convenient online submission

- Thorough peer review

- Inclusion in PubMed and all major indexing services

- Maximum visibility for your research

Submit your manuscript at www.biomedcentral.com/submit 